\title{
PERBEDAAN KUALITAS SPERMA PADA PASIEN PENDERITA DIABETES MELLITUS TIPE 1 DAN 2 DI RSUD. LAMADUKELLENG, SENGKANG, SULAWESI SELATAN
}

\section{DIFFERENCE IN SPERM QUALITY IN PATIENTS WITH TYPE 1 AND 2 DIABETES MELLITUS IN RSUD. LAMADUKELLENG, SENGKANG, SULAWESI SELATAN}

\author{
Andi Ratu Bulqis, ${ }^{1}$ Ni Gusti Ayu Manik Ermayanti, ${ }^{1}$ Ni \\ Nyoman Wirasiti ${ }^{1}$ \\ ${ }^{1}$ Program Studi Biologi, Fakultas Matematika dan Ilmu Pengetahuan Alam, Universitas \\ Udayana, Bali. Email: arbulqis@gmail.com
}

\begin{abstract}
ABSTRAK
Diabetes mellitus merupakan gangguan metabolisme yang disebabkan kurangnya hormon insulin dan menyebabkan kelainan metabolisme karbohidrat, protein dan lemak. Diabetes mellitus akan mempengaruhi beberapa kinerja organ dalam tubuh manusia. Salah satunya yaitu berpengaruh terhadap produksi kualitas sperma pada tubulus seminiferus. Tujuan dilakukan penelitian ini adalah untuk mengetahui perbedaan kualitas sperma pada pasien penderita diabetes mellitus tipe 1 dan 2 di Rumah Sakit Umum Daerah Lamadukelleng, Sengkang. Sampel diambil dari 30 laki-laki yang bersedia sebagai probandus sesuai dengan kriteria yang telah ditentukan yaitu penderita DM tipe 1 dan 2, berumur 20-45 tahun. Kemudian dimasukkan kelompok kontrol, DM 1 dan DM 2 menggunakan metode Komperatif dengan jumlah probandus masing-masing kelompok sebanyak 10 orang. Metode analisa kualitas sperma yang dilakukan di Laboratorium Andrologi, Rumah Sakit Umum Daerah Lamadukelleng, Sengkang adalah makler chamber, kemudian dilakukan pemeriksaan analisa kualitas sperma seperti pada umumnya. Data yang didapat dari hasil penelitian ini berupa data kualitatif dan kuantitatif. Data kualitatif meliputi morfologi, disajikan dalam bentuk gambar. Kemudian data kuantitatif meliputi, penghitungan konsentrasi, motilitas dan morfologi disajikan dalam bentuk tabulasi data. Setelah itu data kuantitatif dibaca dalam metode penghitungan statistik menggunakan SPSS Versi 24, dengan One Way Anova untuk melihat perbedaan antara sampel DM tipe 1 dan 2 yang berbeda signifikan $(\mathrm{p}<0,05)$. Kesimpulan penelitian ini yaitu terdapat perbedaan konsentrasi, motilitas dan morfologi pada pasien penderita DM tipe 1 dan 2.
\end{abstract}

\section{Kata kunci : andrologi, diabetes mellitus, fertilitas, kualitas sperma}

\begin{abstract}
Diabetes mellitus is a metabolic disorder caused by a lack of the hormone insulin and causes abnormalities in carbohydrate, protein and fat metabolism. Diabetes mellitus will affect the performance of several organs in the human body. One of them is affecting the production of sperm quality in the seminiferous tubules. The purpose of this study was to determine differences in sperm quality in patients with type 1 and 2 diabetes mellitus at the Lamadukelleng District General Hospital, Sengkang. Samples were taken from 30 men who were willing as probandus according to predetermined criteria such as DM sufferers type 1 and 2, aged 20-45 years. Then included a control group, DM 1 and DM 2 using the Comparative method with the number of probandus for each group of 10 people. The method of sperm quality analysis conducted at the Andrology Laboratory, Regional Hospital of
\end{abstract}


Lamadukelleng, Sengkang is a makler chamber, then an examination of sperm quality analysis is carried out as usual. Data obtained from the results of this study in the form of qualitative and quantitative data. Qualitative data includes morphology, presented in the form of images. Then the quantitative data includes, calculation of concentration, motility and morphology are presented in the form of tabulated data. After that quantitative data was read in the statistical calculation method using SPSS Version 24, with One Way Anova to see differences between DM types 1 and 2 samples that were significantly different $(\mathrm{p}<0.05)$. The conclusion of this study is that there are differences in concentration, motility and morphology in patients with type 1 and 2 DM.

\section{Keywords : andrology, diabetes mellitus, fertility, sperm quality}

\section{PENDAHULUAN}

Dewasa ini kesehatan di berbagai negara telah mengalami pergeseran pola penyakit. Masalah kesehatan dapat dipengaruhi oleh pola hidup, pola makan, lingkungan kerja, olahraga dan stress. Perubahan gaya hidup ini menyebabkan meningkatnya penyakit degeneratif, seperti penyakit jantung, hipertensi, hyperlipidemia, diabetes mellitus (DM) (Waspadji, 2007). Hal ini ditandai dengan kondisi yang sebelumnya banyak disebabkan oleh penyakit infeksi maupun penyakit menular (communicable disease) kini berganti ke arah penyakit tidak menular (non-communicable disease), penyakit degeneratif. Penyakit tidak menular yang hingga saat ini menunjukkan peningkatan salah satunya adalah diabetes mellitus (DM) (Smeltzer et al., 2002).

Diabetes mellitus (DM) merupakan gangguan metabolisme kompleks yang disebabkan berkurangnya hormon insulin menyebabkan kelainan metabolisme karbohidrat, protein dan lemak. Penyakit ini terbagi dua tipe yaitu DM tipe 1 dan DM tipe 2. DM tife 1 ini disebabkan karena naiknya kadar glukosa dalam darah yang disebabkan oleh rusaknya sel beta pulau Langerhans pada pancreas. Sedangkan DM tipe 2 disebabkan karena kenaikan glukosa darah yang tinggi akibat hilangnya sensitivitas akan insulin (Agus, 2008). Diabetes dapat terjadi pada semua kalangan laki-laki dan perempuan. Diabetes yang terjadi pada lakilaki dapat menyebabkan gangguan aliran darah akibat rusaknya pembuluh yang berada di beberapa bagian tubuh (Suyono, 2014).

Berdasarkan penelitian dari Unit Kerja Koordinasi Endokrinologi Anak di seluruh Indonesia yang diterbitkan Direktorat Jenderal Kemenkes RI pada awal Maret 2012 didapat sekitar 731 anak dan remaja di bawah usia 20 tahun yang sudah mengalami diabetes mellitus (Kemenkes RI, 2012). World Health Organization melaporkan dalam Global Status Report on $N C D$ s bahwa penduduk yang menderita DM pada tahun 2008 adalah berjumlah sekitar 347 juta dan $80 \%$ diantaranya berasal dari negara berkembang. WHO memperkirakan pada tahun 2030, DM akan meningkat (WHO, 2014).

Kondisi penyakit DM yang terus meningkat - menimbulkan kekhawatiran pada laki-laki khususnya, akan keberlangsungan keturunan. Peningkatan prevalensi DM di negara berkembang diakibatkan oleh perubahan pola makan. Penyakit DM -mempengaruhi fungsi reproduksi laki-laki pada berbagai tahap. Sebagai akibat efeknya terhadap proses spermatogenesis (Guneli et al., 2008). 
Menurut penelitian Agbaje et al. (2007), perbedaan kualitas sperma pada pria penderita DM -dan pria normal, berfokus pada konsentrasi, motilitas serta morfologi sperma. Hasil penelitian tersebut menunjukkan bahwa nilai konsentrasi dan motilitas penderita DM lebih rendah -pada pria normal (beda signifikan $\mathrm{p}<0.05$ ), sedangkan morfologi sperma penderita DM terdapat sebesar 53\% kerusakan sperma, dan sebesar 32\% kerusakan morfologi sperma pada laki-laki normal. Sehingga penyakit DM ini dikaitkan dengan peningkatan kerusakan sperma nuklear yang dapat mengganggu kemampuan reproduksi).

Hal tersebut - selaras -dengan kelainan histologi testis tikus diabetes yang -dibuktikan oleh penelitian Adelati, dkk(2016). Terdapat perbedaan

- spermatogenesis testis antara -tikus yang menderita diabetes mellitus, dan tikus normal. - - Hasil penelitian ini menunjukkan bahwa penyakit DM - mengganggu proses spermatogenesis. Secara umum diabetes menyebabkan gangguan pada kualitas sperma khususnya

\section{MATERI DAN METODE}

Materi penelitian ini adalah - sperma - 30 orang laki-laki. Hal ini meliputi lakilaki normal atau bebas penyakit DM tipe 1 maupun tipe 2 sebanyak 10 orang (sebagai kelompok kontrol), penderita penyakit DM 1 dan 2 masing-masing sebanyak 10 orang yang berada di RSUD. Lamadukelleng, Sengkang, Sulawesi Selatan. Jumlah ini sesuai aturan minimum menurut Mahmud tahun (2011). Adapun kriteria sampel yaitu pasien penderita diabetes mellitus tipe 1 dan 2, serta berusia 20-45 tahun. Penelitian ini dilaksanakan pada bulan OktoberDesember 2019, bertempat di Laboratorium Andrologi, Rumah Sakit Umum Daerah pergerakan atau motilitas dan jumlahnya. Tingginya gula darah di dalam tubuh menyebabkan gangguan pada pembuluh darah khususnya yang mengarah ke penis (Corona et al., 2016). Gangguan ini menyebabkan aliran darah tidak -lancar ke penis sehingga nutrisi--untuk perkembangan spermatozoa - di dalam tubulus seminiferus -terganggu (Parhizkar et $a l ., 2013)$. Spermatozoa yang terbentuk di testis membutuhkan energi yang besar dari gula yang diserap oleh tubuh. Spermatozoa -pria yang mengalami diabetes - akut biasanya -akan mengalami penurunan kualitas. Terjadi penurunan jumlah dan gangguan motilitas. Jumlahnya akan menurun - dan pergerakannya terganggu (Alwi dkk., 2006).

Berdasarkan hal tersebut tujuan penelitian ini $=$ untuk mengetahui dan mempelajari hal terkait morfologi, terhadap pasien penderita diabetes mellitus, baik tipe 1 maupun tipe 2. Hasil dari analisa sperma tersebut, dapat dijadikan penambahan ilmu pengetahuan serta dasar untuk pengarahan pemeriksaan lanjutan dari pasien diabetes mellitus.

\section{Materi Penelitian}

Lamadukelleng, Sengkang, Sulawesi Selatan. Penelitian ini telah mendapatkan Ethical Cleararce/Keterangan Kelaikan Etik Nomor: 2846lUN1 4.2.2.V11.141:P12019, dari Rumah Sakit Umum Pusat Sanglah, Denpasar, Bali.

\section{Prosedur Pelaksanaan}

Pelaksanaan penelitian ini dimulai dari persiapan alat kerja yang meliputi sperm container, shaker, hand counter, mikroskop Olympus, gloves, tissu, label nama, gelas obyek, cover glass, makler chamber, gelas ukur, pipet tetes dan form report pasien. Serta bahan yang digunakan 
yaitu cairan sperma pasien, aquades, minyak emersi, alkohol $70 \%$, etanol $95 \%$, safranin $1 \%$, dan kristal violet $2 \%$.

\section{Persiapan Sampel}

Pertama, spermatozoa container dipersiapkan dengan steril. Kedua, pasien dipersilahkan masuk dalam ruangan yang telah ditentukan oleh petugas laboratorium untuk melakukan proses pengeluaran cairan sperma dengan cara masturbasi kemudian sperma ditampung menggunakan sperma container (dengan minimal pasien abstinensia selama 2 hari dan maksimal 7 hari). Ketiga, formulir pasien dipersiapkan untuk mencatat tanggal tindakan pemeriksaan, identitas pasien (nama suami dan istri, umur), serta keterangan masa abstinensia.

\section{Pengamatan Mikroskopik}

Pengamatan mikroskopik meliputi konsentrasi, motilitas dan morfologi berdasarkan acuan dari World Health Organization tahun (2010) sebagai berikut:

a. Penghitungan konsentrasi: cairan sperma diambil dengan pipet dan diteteskan pada makler chamber kemudian di tutup dengan kaca penutup. Setelah itu diamati di bawah mikroskop dengan perbesaran 400x dengan cara perhitungan 3 baris chamber secara acak bila jumlah sperma > 20/baris pertama lalu dibagi rata-rata dan dikali $10^{6} / \mathrm{mL}$. Namun bila sperma $<20 /$ baris pertama maka baris yang dihitung berjumlah 10 kemudian dirata-ratakan lalu dikalikan $10^{6} / \mathrm{mL}$.

b. Penghitungan motilitas: cairan sperma diambil dengan pipet dan diteteskan pada makler chamber kemudian di tutup dengan kaca penutup. Setelah itu diamati di bawah mikroskop dengan perbesaran 400x dengan cara perhitungan 3 baris chamber secara acak bila jumlah sperma > 20/baris pertama (sperma yang dihitung dengan 3 kriteria yaitu Progressive, Non-progressive dan Immotile). Namun bila sperma < 20/baris pertama maka baris yang dihitung berjumlah 10 . Kemudian, dibagi rata-rata dari jumlah kriteria dan dihitung persentase.

c. Penghitungan morfologi: cairan sperma diteteskan di bagian ujung gelas obyek setelah itu dilakukan apusan dengan meratakan sperma dengan gelas obyek lainnya (digerakkan kearah belakang dengan sudut 45 derajat) dan dianginkan hingga kering. Setelah itu, ditetesi dengan etanol $95 \%$ dan dikeringkan dengan posisi berdiri. Selanjutnya, ditetesi dengan larutan safranin $1 \%$ dibiarkan selama 10 menit hingga kering dengan posisi sama. Selanjutnya, ditetesi dengan larutan kristal violet $2 \%$ dibiarkan selama 10 menit dan dikeringkan dengan posisi sama. Terakhir, diamati di bawah mikroskop perbesaran 1000x dengan tambahan minyak emersi pada lensa mikroskop. Sperma normal dan abnormal dihitung hingga 100 dan dihitung persentasenya.

\section{Metode Pengolahan Data}

Penelitian ini menggunakan metode Komperatif dengan 3 kelompok dan jumlah probandus masing-masing kelompok sebanyak 10 orang. Kemudian data yang didapat dari hasil penelitian ini berupa data kualitatif dan kuantitatif. Data kualitatif meliputi morfologi, disajikan dalam bentuk gambar. Serta data kuantitatif meliputi penghitungan konsentrasi, motilitas, dan morfologi, disajikan dalam bentuk tabulasi data. Setelah itu data dibaca dalam 
penghitungan statistik menggunakan SPSS Versi 24, dengan One Way Anova untuk melihat perbedaan antara sampel DM tipe 1 dan 2 yang berbeda signifikan ( $p<0,05)$.

\section{HASIL}

Berdasarkan hasil penelitian yang dilakukan di Laboratorium Andrologi, Rumah Sakit Umum Daerah Lamadukelleng, Sengkang, maka di dapatkan hasil melalui pengolahan data statistik SPSS Versi 24, sebagai berikut:

Tabel 1 ANOVA

\begin{tabular}{|ll|r|r|r|r|r|}
\hline & & Sum of Squares & df & Mean Square & F & Sig. \\
\hline KONSENTRASI & Between Groups & 835.782 & 2 & 417.891 & 37862.607 & .000 \\
& Within Groups & .298 & 27 & .011 & & \\
& Total & 836.080 & 29 & & & \\
\hline MOTILITAS & Between Groups & 3163.400 & 2 & 1581.700 & 2259.571 & .000 \\
& Within Groups & 18.900 & 27 & .700 & & \\
& Total & 3182.300 & 29 & & & \\
\hline MORFOLOGI & Between Groups & 7886.667 & 2 & 3943.333 & 1645.595 & .000 \\
& Within Groups & 64.700 & 27 & 2.396 & & \\
& Total & 7951.367 & 29 & & & \\
\hline
\end{tabular}

Berikut adalah gambar-gambar dari berbagai morfologi sperma ditemukan pada penelitian ini yang tergolong dalam bentuk sperma tidak normal (abnormal):

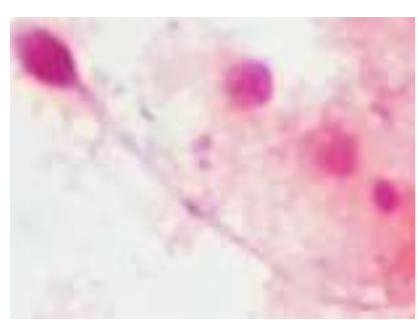

(1)

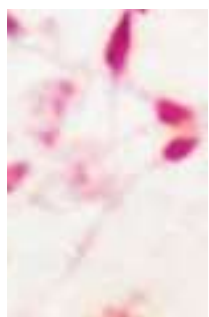

(2)

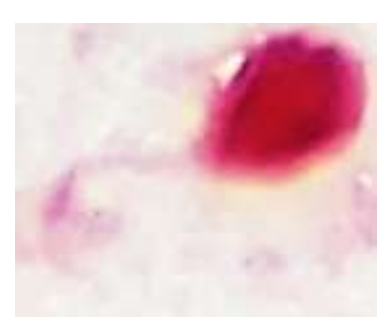

(3)

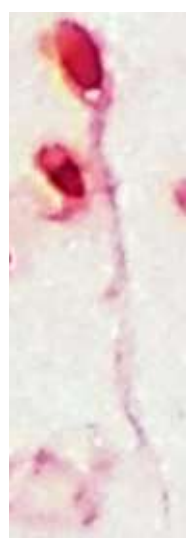

(4)

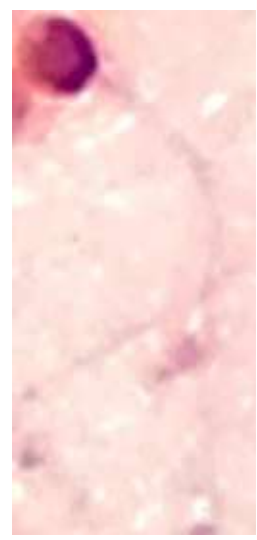

(5)

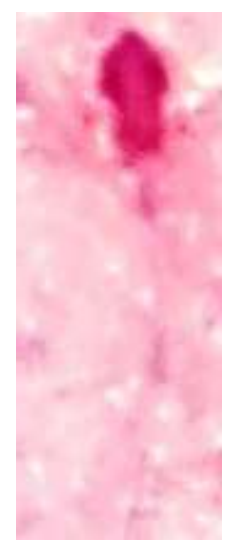

(6)

Keterangan: (1) normal, (2) meruncing, (3) besar, (4) terlalu oval, (5) terlalu bulat, (6) tidak berbentuk

Gambar 1. Abnormalitas kepala sperma dengan perbesaran 1000x 


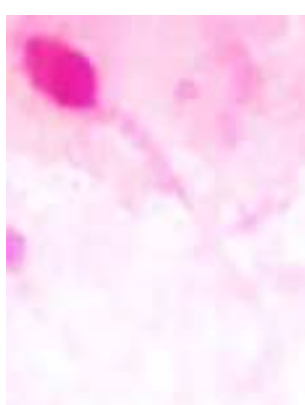

(1)

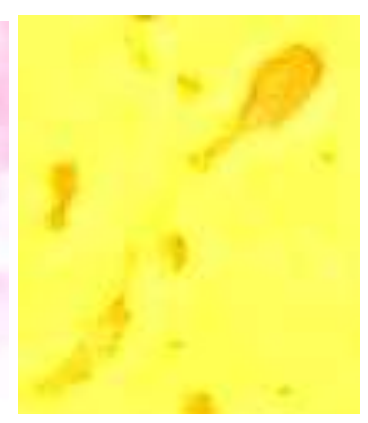

(2)

Keterangan: (1) menebal, (2) putus

Gambar 2. Abnormalitas leher sperma dengan perbesaran 1000x

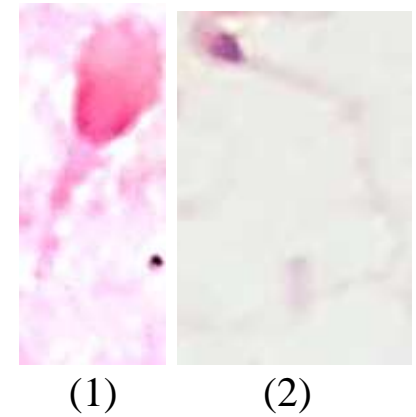

Keterangan: (1) pendek, (2) patah

Gambar 3. Abnormalitas ekor sperma dengan perbesaran 1000x

\section{PEMBAHASAN}

Penelitian yang dilakukan di Laboratorium Andrologi, Rumah Sakit Umum Daerah Lamadukelleng, Sengkang, menunjukan adanya perbedaan konsentrasi, motilitas dan morfologi dari pasien normal dengan pasien penderita DM tipe 1 dan tipe 2 yang secara statistik memiliki nilai yang signifikan berbeda nyata.

Menurut Ding et al. (2015), salah satu hal penting kemungkinan terjadi pada penderita diabetes adalah gangguan sistem reproduksi pria. Hal ini dikarenakan terganggunya metabolisme glukosa dalam proses spermatogenesis. Penyakit diabetes dapat merusak fungsi seksual seperti sel sperma, hingga ke fragmen DNA. Kerusakan yang rentan terjadi pada sel sperma dapat disebabkan oleh tingginya kadar dari stres oksidatif akibat tinggi kadar asam lemak tidak jenuh dan defisiensi dari proteksi antioksidan.
Penelitian memberikan gambaran yang serupa dengan teori yang sudah ada, dapat dilihat dari Tabel 1. Anova, bahwa terdapat perbedaan yang signifikan yakni ( $p$ $<0,01)$ antara penderita DM 1 dengan DM 2. Pada penderita DM tipe 1 konsentrasi sperma digolongkan pada kriteria ekstrim oligospermia, sedangkan pada penderita DM tipe 2 yaitu golongan oligospermia. Konsentrasi sperma per ejakulat menjadi indikasi akan banyaknya sperma yang ada pada laki-laki. Pada penelitian ini terlihat selaras dengan teori yang menyatakan bahwa penderita diabetes akan mengalami gangguan reproduksi (Amilia, 2009). Penyebab adanya gangguan pada reproduksi penderita diabetes karena ateroskeleris pada saluran darah dan cabang-cabangnya sehingga terjadinya penghambatan suplai nutrisi bagi perkembangan sperma di tubulus seminiferus (Evy dkk., 2012). 
Kondisi penderita diabetes, yakni terganggu kerja hormon insulin sehingga glukosa banyak menumpuk di aliran darah. Keadaan ini disebut hiperglikemi (Chandrashekar and Muralidhara, 2009). Keadaan hiperglikemi dan defisiensi insulin dapat mempengaruhi struktur ataupun fungsi jaringan. Hiperglikemi ini akan meningkatkan Reactive Oxygen Spesies (ROS) yang keadaan ini dapat menyebabkan gangguan spermatogenesis di tubulus seminiferus. Penyakit diabetes selain dapat menyebabkan gangguan spermatogenesis, juga dapat mengakibatkan gangguan fungsi kelenjar seks aksesori. Kejadian ini berhubungan dengan peningkatan ROS. Pada penderita diabetes melitus peningkatan ROS dapat merusak membran mitokondria sehingga kehilangan fungsi potensial membran mitokondria dalam menginduksi apostosis sel sperma (Dalimartha, 2004).

Penyakit diabetes tidak hanya menyebabkan penurunan pada konsentrasi sperma namun juga mengganggu pergerakan sperma. Hal ini dapat terlihat pada tabel hasil statistik, nilai motilitas juga signifikan $(\mathrm{p}<0,01)$. Rendahnya tingkat pergerakan sperma pada pasien penderita diabetes, diakibatkan adanya gangguan spermatogenesis dari mikroangiopati pada kondisi hiperglikemi yang mengganggu pemberian nutrisi pada tubulus seminiferus dan apoptosis sel spermatogenik (Arikawe et al., 2006). Menurut Soehadi (1996), bahwa sperma yang perkembangannya terhambat akan mengalami berbagai kelainan, baik berupa kelainan morfologi maupun menurunnya kualitas hidup spermatozoa. Kemudian hal lain juga bisa diakibatkan karena adanya inflamasi pada saluran reproduksi laki-laki, yang kemudian mengakibatkan penurunan pergerakan sperma (Omolaoye dan Stefan, 2018).
Inflamasi pada saluran reproduksi laki-laki dapat dilihat pada jumlah leukosit yang ada di cairan sperma (WHO, 2010). Hal ini juga dapat ditandai dengan warna kekuningan pada cairan sperma. Kemudian jika inflamasi terjadi pada saluran kelenjar reproduksi laki-laki maka akan terjadi perbedaan bau dari cairan sperma laki-laki normal (Bagdade et al., 1978). Teori ini diperkuat dengan adanya bau serta warna kekuningan yang didapatkan pada sampel cairan sperma pasien penderita diabetes terkhususnya DM tipe 1 pada penelitian ini. Menurut Bener et al. (2009), banyaknya faktor yang terjadi pada saluran reproduksi laki-laki akan menyebabkan terganggunya sistem reproduksi dan kualitas spermanya.

Kerusakan lainnya yaitu pada struktur atau bentuk sperma. Gambar sperma yang normal dan cacat atau abnormal dapat dilihat pada hasil. Jenis kerusakan sperma meliputi bagian kepala, leher dan juga ekor. Pengamatan bentuk sperma ini dengan perbesaran 1000x. Abnormalitas spermatozoa yang meningkat juga dapat terjadi akibat berbagai gangguan terutama pada proses spermatogenesis, ditahap spermiogenesis (penyempurnaan bentuk sperma) (Ermayanti dan Suarni, 2010).

Perubahan bentuk sperma tersebut karena penurunan kadar hormon testosteron yang secara fungsional epididimis tergantung pada hormon tersebut di proses perubahan atau pembentukan sperma sempurna. Sehingga jika kadar testosteron menurun maka menyebabkan terjadinya morfologi sperma yang abnormal (Erris dan Harahap, 2014). Bentuk morfologi sperma juga memiliki peran pada proses pembuahan. Jika jumlah abnormalitas sperma terlalu tinggi maka dapat mempengaruhi daya fertilitas. Hal ini berhubungan pada saat proses sperma 
menuju sel telur dalam proses menembus sel telur. Jika terjadi kerusakan pada salah satu bagian sperma maka akan mempengaruhi keterlambatan ataupun kegagalan fertilisasi (Busman, 2007).

Laki-laki yang pada keadaan normal dalam proses spermatogenesisnya akan terjadi proses pelepasan hormon gonadotropin dari hipotalamus, sehingga akan merangsang hipofisis anterior untuk pengeluaran hormon-hormon lainnya yakni luteinizing hormone (LH) dan follicle stimulating hormone (FSH). Hormonhormon tersebut berperan dalam proses spermatogenesis (Khourdaji et al., 2018). Hormon luteinizing selanjutnya akan merangsang sel Leydig untuk mensekresi hormon testosteron dan dihidrotestosteron,

\section{SIMPULAN}

Berdasarkan hasil dan pembahasan di atas maka dapat ditarik simpulan yaitu ada perbedaan konsentrasi, motilitas dan morfologi sperma antara kontrol dengan pasien penderita DM tipe 1 dan DM tipe 2. Konsentrasi dan motilitas sperma pasien penderita DM tipe 1 lebih rendah daripada pasien DM tipe 2, serta morfologi pasien DM tipe 1 lebih banyak kerusakan daripada pasien DM tipe 2.

\section{SARA}

$\mathbf{N}$

Saran dari penelitian ini adalah dibutuhkan uji lebih lanjut mengenai penyebab terjadinya perubahan warna dan bau pada cairan sperma pasien penderita DM tipe 1. Dibutuhkan pewarnaan sperma yang lebih baik serta perbesaran mikroskop lebih tinggi agar dapat melihat struktur kepala, leher dan ekor dari sperma manusia yang lebih jelas.

\section{DAFTAR \\ PUSTAKA}

Adelati, S., A. Z. Juniarto, dan I. P. Miranti. 2016. Histopatologi Spermatogenesis sementara FSH akan berproses dalam merangsang sel sertoli di tubulus seminiferus untuk membantu proses spermatogenesis. Namun jika terjadi defisiensi hormon insulin atau ketidakpekaan terhadap insulin pada penderita diabetes maka akan terjadi perubahan jalur hormon endokrin dalam sistem umpan balik negatif ke hipofisis anterior. Mekanisme ini berawal dari adanya aktivitas konversi hormon testosteron menjadi hormon estrogen, sehingga kadar hormon testosteron semakin rendah. Serta peningkatan hormon estrogen ini memicu hipofisis anterior untuk mengurangi sekresi hormon LH dan FSH yang mengakibatkan gangguan fungsi reproduksi pria (Ballester et al., 2004).

Testis Tikus Wistar Diabetes mellitus. Jurnal Kedokteran Diponegoro. 5 (4): 1760-1769.

Agbaje, I. M., D. A. Rogers, D. A. McVicar, N. McClure, A. B. Atkinson, and C. Mallidis. 2007. Insulin Dependant Diabetes mellitus: Implications for Male Reproductive Function. Human Reproduction. 22 (7): 1871-1877.

Agus, R. 2008. Kadar Gula Darah Dan Kadar Hormon Testosteron Pada Pria Penderita Diabetes Mellitus. Tesis. Universitas Diponegoro. Semarang.

Alwi, I., B. Setiyohadi, dan A. W. Sudoyono. 2006. Buku Ajar Ilmu Penyakit Dalam. Ed V. Jilid III. Interna Publishing. Jakarta.

Amilia, D. U. 2009. Profil Sel B Pulau Langerhans Jaringan Pankreas Tikus Diabetes mellitus yang diberi Virgin Coconut Oil (VCO). Skripsi. Fakultas Kedokteran Hewan. Institut Pertanian Bogor.

Arikawe, A. P., A. O. Daramola, A. O. Odofin, and L. F. O. Obika. 2006. 
Alloxan-induced and Insulinresistant Diabetes mellitus affect Semen Parameters and Impair Spermatogenesis in Male Rats. Afr $J$ Reprod Health. 10 (3):106-113.

Bagdade, J. D., M. Stewart, and E. Walters. 1978. Impaired Granulocyte Adherence A Reversible Defect in Host Defensein Patients with Poorly Controlled Diabetes. Diabetes. 27 (6): 677-681.

Ballester, J., M. C. Munoz, J. Dominguez, T. Rigau, J. J. Guinovart, and G. J. E. Rodriguez. 2004. Insulin Dependent Diabetes Affects Testicular Function by FSH and LH Linked Mechanisms. Journal of Andrology. 25 (5): 706719.

Bener, A., M. Zirie, A. Al-Ansari, and A. O. Al-Hamaq. 2009. Is Male Fertility Associated with Type 2 Diabetes mellitus. International Urology Nephrology. 41:777-784.

Busman, H. 2007. Kualitas Spermatozoa Mencit Jantan (Mus musculus) Akibat Fequency Electric Field. Erlangga. Jakarta.

Chandrashekar, K. N., and Muralidhara, 2009. Evidence of Oxidative Stress and Mitochondrial Dysfunctions Inthe Testis of Prepubertal Diabetic Rats. Int JImpot Res. 3 (21): 198-206.

Corona, G., C. B. Giord, D. Cucinotta, P. Guida, and E. Nada. 2016. Sexual Dysfunction in Type 2 Diabetes at Diagnosis: Progression over Time and Drug an Non Drug Correlated Factor. Cross Mark. 11 (10).

Dalimartha, S. 2004. Ramuan Tradisional untuk Pengobatan Diabetes melitus. Cetakan 9. Penebar Swadaya. Jakarta.

Ding, G. L., Y. Liu, E. L. Miao, J. X. Pan, M. X. Guo, J. Z. Sheng, and H. F. Huang. 2015. The Effects of Diabetes on Male
Fertility and Epigenetic Regulation during Spermatogenesis. Asian Journal of Andrology. 17 (6).

Ermayanti, N. G. A. M., dan N. M. R. Suarni. 2010. Kualitas Spermatozoa Mencit (Mus musculus L.) Setelah Perlakuan Infus Kayu Amargo (Quassia amara Linn.) dan Pemulihannya. Jurnal Biologi. 14 (1): 45-49.

Erris dan I. Harahap. 2014 Pengaruh Kebisingan terhadap Kuantitas dan Kualitas Spermatozoa Tikus Putih (Rattus norvegicus) Jantan Dewasa. Media Litbangkes. 24 (3): 123-128.

Evy, S., Setiawati, H. Nindyastuti, dan A. N. Putra. 2012. Infusa Daging Buah Mahkota Dewa Memperbaiki Kerusakan Testis dan Parameter Sperma Tikus Diabetik. Jurnal Kesehatan. 4 (2): 115-123.

Guneli, E., A. Tugyan, H. Ozturk, H. Gumustekin, S. Cilaker, and N. Uysal. 2008, Effect of Melatonin on Testicular Damage in StreptozotocinInduced Diabetes Rats. European Surgical Research. 40: 354-360.

Kementrian Kesehatan Republik Indonesia. 2012. Survei Demografi dan Kesehatan Indonesia. Kementrian Kesehatan Republik Indonesia. Jakarta.

Khourdaji, I., L. Haerin, and P. S. Ryan. 2018. Frontiers in Hormone Therapy for Male Infertility. Transl Androl Urol. 7(3): 353-366.

Mahmud. 2011. Metode Penelitian Pendidikan. Pustaka Setia. Bandung.

Omolaoye, T. S., and D. P. Stefan. 2018. Diabetes mellitus and Male Infertility Asian Pacific Journal of Reproduction. 7 (1): 6-14.

Parhizkar, S., M. J. Yusoff, and M. A. Dollah. 2013, Effect of Phaleria 
Macrocarpa on Sperm Characteristics in Adult Rats. Adv Pharm Bull. 3 (2): 345-52.

Smeltzer, C. S., G. Bare, and Brenda., 2002. Buku Ajar Keperawatan Medikal Bedah. Alih Bahasa: dr. H. Y. Kuncara. EGC. Jakarta.

Soehadi, K. 1996. Diabetes melitus Pria Profil Spermiogram, Hormon Reproduksi dan Potensi Seks. Universitas Airlangga. Surabaya.

Suyono, S. 2014. Buku Ajar Ilmu Penyakit Dalam: Diabetes mellitus di Indonesia Edisi Ke-6. Interna Publishing: Jakarta.
Waspadji, S. 2007. Pedoman Diet Diabetes mellitus. Fakultas Kedokteran Universitas Indonesia. Jakarta.

World Health Organization. 2010. Examination and Processing of Human Semen $5^{\text {th }}$ Edition. World Health Organization. Switzerland.

World Health Organization. 2014. World Health Statistic 2014. Geneva: World Health Organization. Available at: <http://apps.who.int/iris/ bitstream/10665/112738/1/97892406 92671_eng.I. (10 September 2019). 
SIMBIOSIS VIII (1 ):17-27

Program Studi Biologi FMIPA UNUD

\section{Lampiran 1 Homogenitas}

Test of Homogeneity of Variances

\begin{tabular}{|l|r|r|r|r|}
\hline & Levene Statistic & df1 & df2 & \multicolumn{1}{c|}{ Sig. } \\
\hline KONSENTRASI & .180 & 2 & 27 & .837 \\
MOTILITAS & .199 & 2 & 27 & .821 \\
MORFOLOGI & .872 & 2 & 27 & .429 \\
\hline
\end{tabular}

\section{Lampiran 2 Descriptive statistic}

Descriptives

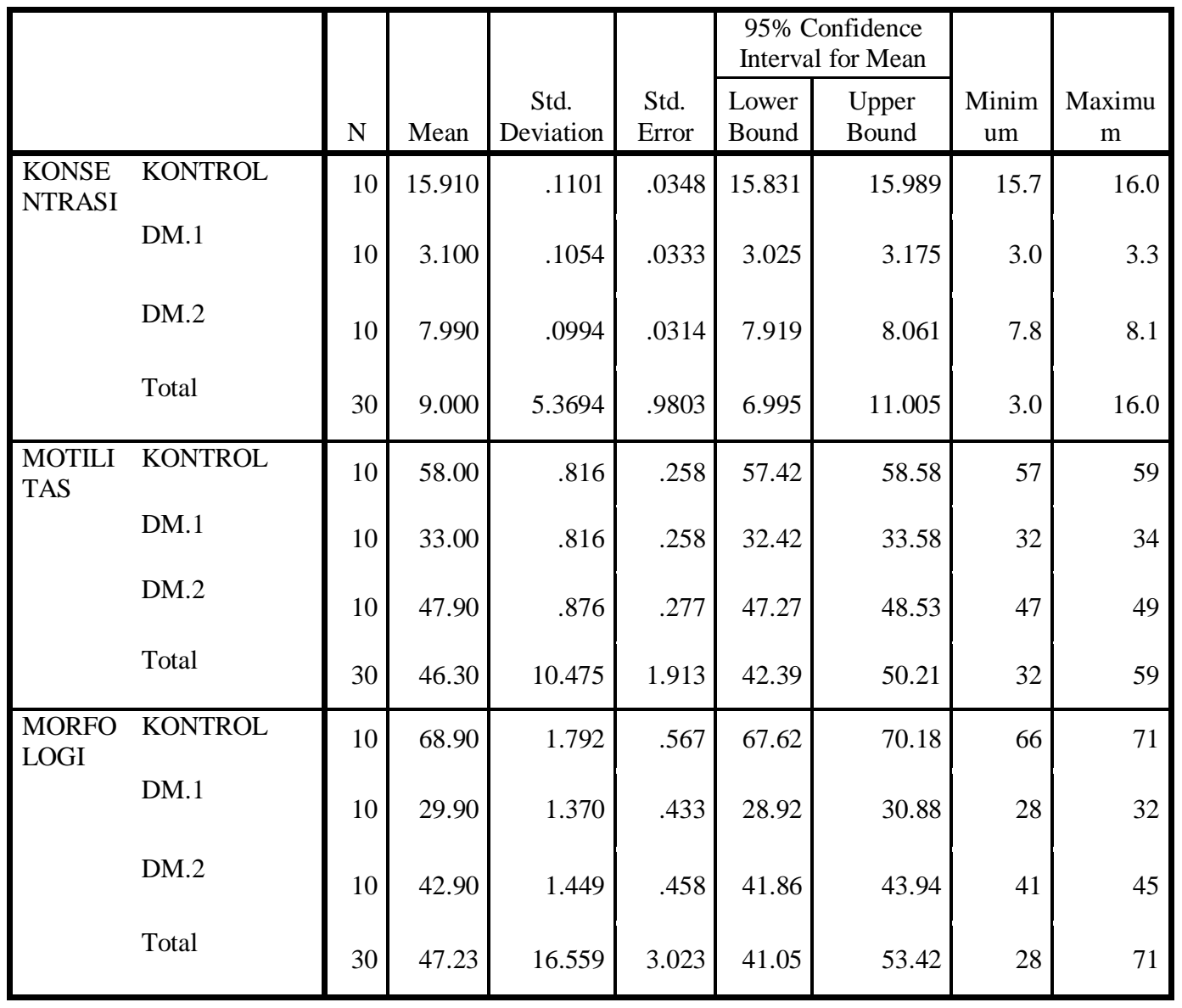

